\title{
Development towards an experimental protocol for the transmission of pancreas disease of Atlantic salmon Salmo salar
}

\author{
Robert S. Raynard, Gillian Houghton \\ SOAFD Marine Laboratory, PO Box 101, Victoria Road, Aberdeen AB9 8DB, United Kingdom
}

\begin{abstract}
The widespread loss of exocrine pancreas secretory acinar cells, similar to the pathology observed in Atlantic salmon Salmo salar affected by pancreas disease, was reproducibly transmitted to salmon parr in fresh water by intraperitoneal injections of homogenised kidney and spleen removed from affected fish. In fresh water the prevalence of pancreas pathology in experimental populations increased to a maximum of 40 to $70 \%$ over 2 to $4 \mathrm{wk}$ followed by an apparent recovery within a further $4 \mathrm{wk}$. In sea water fish the incidence of affected salmon was lower and the temporal pattern of progression more varied than was the case in fresh water. Infectious pancreatic necrosis virus was not detected in experimental fish or homogenised fish tissues. In both fresh and sea water the incidence of the pancreas pathology was dependent upon the dose of homogenate injected. Preliminary results indicate that experimentally affected fish in sea water are less likely to feed than non-affected fish. Evidence supporting an infectious cause of the pancreas pathology included: findings consistent with the replication of the causative agent in fish tissue, transmission to salmon cohabited with affected animals and no diminution in the effectiveness of homogenates in transmitting the pancreas pathology after $0.22 \mu \mathrm{m}$ filtration
\end{abstract}

\section{INTRODUCTION}

Pancreas disease is a condition of farmed Atlantic salmon which was first recorded in 1976 (Munro et al. 1984). The major pathological characteristic of the disease is the degeneration and widespread loss of acinar cells of the exocrine pancreas (Munro et al. 1984, McVicar 1987).

Epidemiological evidence obtained from salmon farms in Scotland was judged by McVicar (1987) to support the idea that pancreas disease had an infectious cause. However, a pathogen which can cause pancreas disease has not yet been identified or isolated. The first experimental evidence that pancreas disease was transmittable and, therefore, might be infectious was presented by McVicar $(1987,1990)$. The exocrine pathology which was typical of pancreas disease was reproduced in previously healthy salmon by injecting homogenised kidney dissected from salmon in the early stages of the disease. However, in our own studies of pancreas disease, the method for experimen- tal transmission described by McVicar (1990) resulted in variable success particularly for salmon in sea water when it was often not possible to transmit the disease. Since other workers have communicated to us their difficulties in transmitting the disease the primary purpose of the present paper is to describe our attempts to investigate possible causes of this variability

\section{MATERIALS AND METHODS}

Terminology. For convenience, and in the absence of proof of an infectious agent causing pancreas disease, the term infective is used to describe putatively infectious material derived from previously affected populations of fish.

Preparation of homogenates. Large batches of control and putatively infective material were made by the following procedure. A total of 650 parr in fresh water (temperature $13^{\circ} \mathrm{C}$, mean weight $18 \mathrm{~g}$ ) were injected with $0.1 \mathrm{ml}$ of putatively infective or control material 
(McVicar 1990) diluted 1:10 (v/v) with PBS pH 7.2, without magnesium or calcium (Gibco). Five days after injection, kidneys were asceptically removed from 600 fish, from each group, and stored on ice until they were homogenised in an equal volume of PBS and filtered $(120 \mu \mathrm{m})$ before storage in liquid nitrogen. The remaining 50 fish in control and experimental populations were maintained and monitored by histological examination at intervals to confirm subsequent absence or presence of acinar cell loss respectively. Further batches of kidney homogenates were made by injecting parr with aliquots of the above kidney homogenates. Additionally, homogenates of spleen were prepared as above. Homogenates were filtered using a $0.22 \mu \mathrm{m}$ (Millipore) membrane filter. Pools of infective materlal generated at differeni times were sidndardised on the empirical basis of their protein concentration (Sigma Chemical Co. Ltd, procedure 690).

Injection of fish. Control and experimental fish in each trial received standardised, body weight corrected ( $\mu \mathrm{g}$ control or infective homogenate protein $\mathrm{g}^{-1}$ body weight) intraperitoneal injections of $0.1 \mathrm{ml}$.

Fish. Atlantic salmon were reared at the fish cultivation unit of the Scottish Office Agriculture and Fisheries Department (SOAFD), Aultbea, Wester Ross, Scotland. The absence of pancreas disease and infectious pancreatic necrosis (IPN) was established for all stocks prior to their use (Smail \& Munro 1989). Unless otherwise stated, fish which were injected with control homogenates were always held in different tanks from fish which were injected with infective homogenates Salmon parr were maintained in $1 \mathrm{~m}$ diameter tanks containing $350 \mathrm{l}$ of water, supplied at ca $10 \mathrm{l} \mathrm{min} \mathrm{m}^{-1}$ tank $\mathrm{k}^{-1}$. Salmon post-smolts were maintained in $1 \mathrm{~m}$ diameter tanks containing sea water, supplied at a rate of ca $101 \mathrm{~min}^{-1}$ Fish were fed (Mainstream diets, BP Nutrition) to satiation. Since the water temperature was seasonally variable temperatures for specific experiments are indicated in the results. Prior to all experimental procedures fish were anaesthetised using ethyl-4-aminobenzoate (benzocaine, BDH Chemicals, Poole, Dorset, UK\}.

Diagnosis of pancreas disease. Fish were subjected to histological examination. (Munro et al. 1984) at various intervals after injection. Fish were classified as affected when the normal acinar arrangement of the exocrine pancreas secretory cells had become transformed into one of total apparent necrosis and when no zymogen containing cells (eosinophilia) could be observed. In practice, fish with altered pancreas histology but with a few intact acinar cells were encountered. These fish were classified as non-affected, along with fish having normal pancreas appearance. They probably represent salmon in an intermediate stage of the disease. It was considered impractical to establish a satisfactory, unbiased scoring system for these intermediate fish.

Transmission by cohabitation. Forty salmon postsmolts were injected with infective spleen homogenate and maintained in the same tank as 40 non-injected fish. The mean weight of fish was $130.2 \pm 14.6 \mathrm{~g}$ and each fish received a spleen homogenate dose of $15 \mu \mathrm{g}$ protein $\mathrm{g}^{-1}$ body wt. Water temperature was $14^{\circ} \mathrm{C}$ and samples of 10 fish from each group were assessed for pancreas histology at weekly intervals.

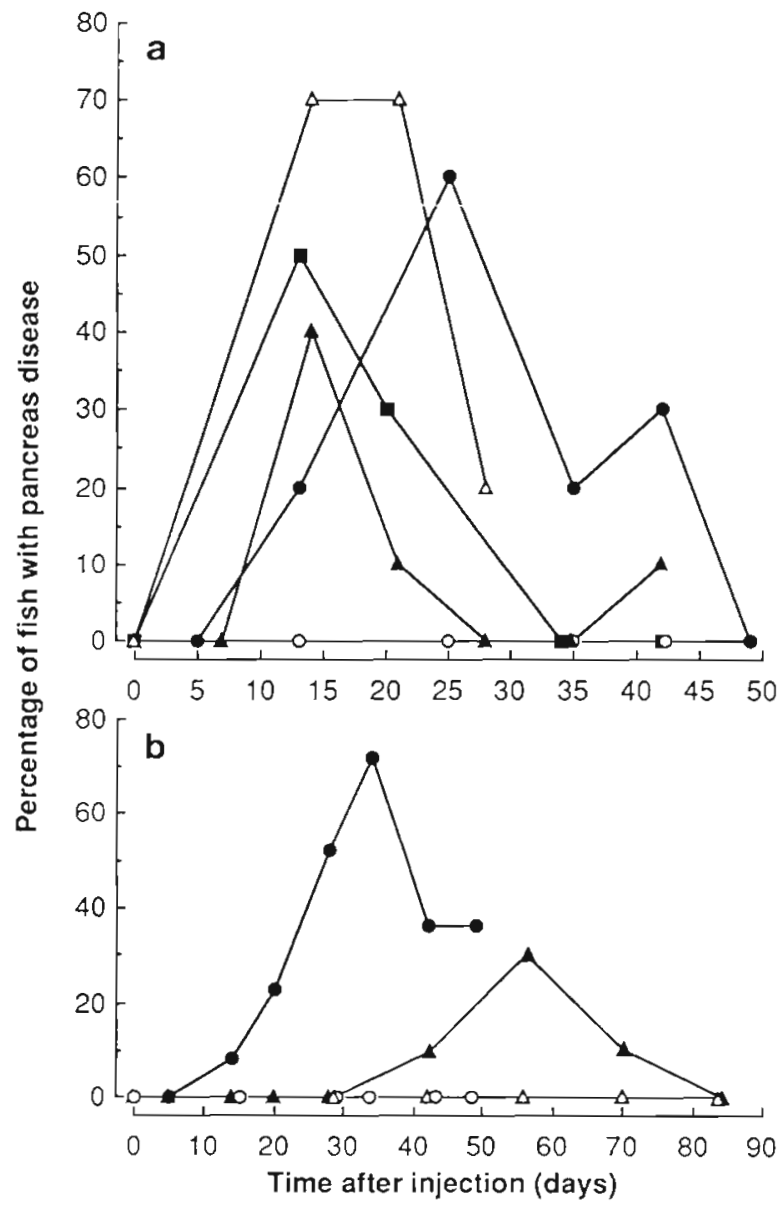

Fig. 1 Salmo salar. Development of complete acinar cell loss in potential \$2 sal.mon parr in fresh water following injection with kidney homogenates. (a) Results of 4 experiments. Fish were 13 to $31 \mathrm{~g}$ and water temperature varied from 10 to $20^{\circ} \mathrm{C}$ between experiments. All fish were injected with kidney homogenates at a dose of $3 \mu \mathrm{g}$ protein $\mathrm{g}^{-1}$ body wt. Expts 1 to 3 (口, $\Delta$ and $)$ used the same batch of kidney material. Expt 4 (L) used a different batch of kidney material. (O) controls for Expt 3. All experiments used control fish, none of which showed altered pancreas histology (results only shown for 1 experiment). Each point represents a subsample of 10 fish from an initial population of 70 . (b) Results of 2 experiments Fish weighed 14 to $18 \mathrm{~g}$ and received $30 \mu \mathrm{g}$ protein $\mathrm{g}^{-1}$ body weight. Expt 1 (water temperature $13^{\circ} \mathrm{C}$ ): (1) experimental fish $_{i}(0)$ control fish. Expt 2 (water temperature was $2^{\circ} \mathrm{C}$ : $(\boldsymbol{\Delta})$ experimental fishi $(\Delta)$ control fish. Each point represents a sample of 25 fish 


\section{RESULTS}

\section{Typical experimental} observations in fresh water

The kinetics of the pancreas histological alteration following in jection at $3 \mu \mathrm{g}$ protein $\mathrm{g}^{-1}$ body wt is shown in Fig. 1a. Results were essentially similar in all experiments, the number of fish in the affected category initially increasing to reach maximal levels in the range 40 to $70 \%$, some 12 to $24 \mathrm{~d}$ after injection. Characteristically the rapid increase in affected salmon was followed by an equally rapid decrease as, presumably. previously affected salmon regenerated pancreas tissue. Fig. 2a shows a histological section of the pancreas from a salmon parr treated as a control. Fig. 2b shows a similarly prepared section from a fish which has developed acinar cell loss following experimental transmission. The differences in the condition of the exocrine pancreas is readily apparent while other tissues such as the areas of fat storage cells and alimentary canal appear unaffected. Although relevant experiments were conducted at different times and on different sized fish, evidence was noted of a temperature effect on the time course of acinar cell loss following injection of infective material. For instance, following injection of infective material at $30 \mu \mathrm{g}$ protein $\mathrm{g}^{-1}$ body wt the process of acinar cell loss was slower in a trial conducted at $2^{\circ} \mathrm{C}$ than in one conducted at $13^{\circ} \mathrm{C}$ (Fig. 1b). In summary, although injection rates varied, injection of infective kidney homogenates at $3 \mu \mathrm{g}$ protein $\mathrm{g}^{-1}$ body wt under fresh water conditions always led to some fish ( $>20 \%$ ), becoming affected.

\section{Effect of dose on transmission in fresh water}

The rate of development of acinar cell loss under fresh water conditions at different doses is shown, separately, for 2 homogenate pools in Fig. 3a, b. The char- acteristic response was seen in both trials when fish received $3 \mu \mathrm{g}$ protein $\mathrm{g}^{-1}$ body wt. In the range 0.3 to $0.03 \mu \mathrm{g}$ protein $\mathrm{g}^{-1}$ body wt markedly fewer fish become affected. In the first trial (Fig. 3a) affected fish were seen at several sampling times, whilst in the second trial (Fig. 3b) affected individuals occurred at the same timing as those at the higher concentration. For reasons of economy of use of valuable experimental material a standard protocol using $3 \mu \mathrm{g}$ protein $\mathrm{g}^{-1}$ body wt has since been settled upon for fresh water experiments. 

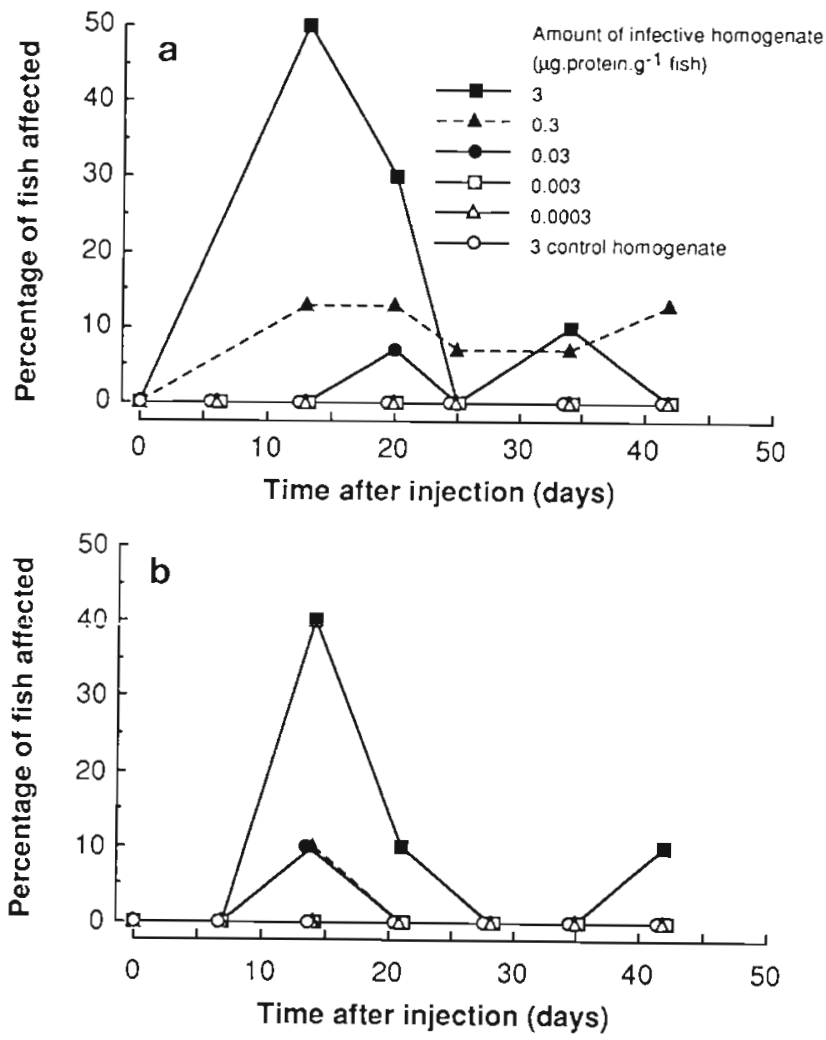

Fig. 3. Salmo salar. The relationship between the amount of kidney homogenate injected and the development of complete acinar cell loss in potential S2 salmon parr in fresh water using 2 different preparations of kidney homagenates. (a) Fish mean weight ( \pm SD) $31 \pm 5.1 \mathrm{~g}$, temperature $20^{\circ} \mathrm{C}$. Each point represents a sample of 15 fish. (b) Fish mean weight $18 \pm 3.6$, temperature $17^{\circ} \mathrm{C}$. Each point represents a sample of $10 \mathrm{fish}$

\section{Effects of filtration on transmission}

Filtering kidney homogenates $(0.22 \mu \mathrm{m})$ did not diminish the ability to cause widespread loss of pancreas acinar cells.

\section{Experiments in sea water}

Affected fish were seen when salmon in sea water were injected with infective kidney material. However, the incidence was lower and the temporal pattern of progression of acinar cell loss was markedly more variable under sea water conditions (Fig. 4). Some trials in sea water were negative, a condition never seen in fresh water. The relationship between the maximal incidence of affected fish and the dose of material injected under sea water conditions was investigated in 2 experiments. In one experiment the incidence of pancreas disease increased as the dose of kidney homoge-

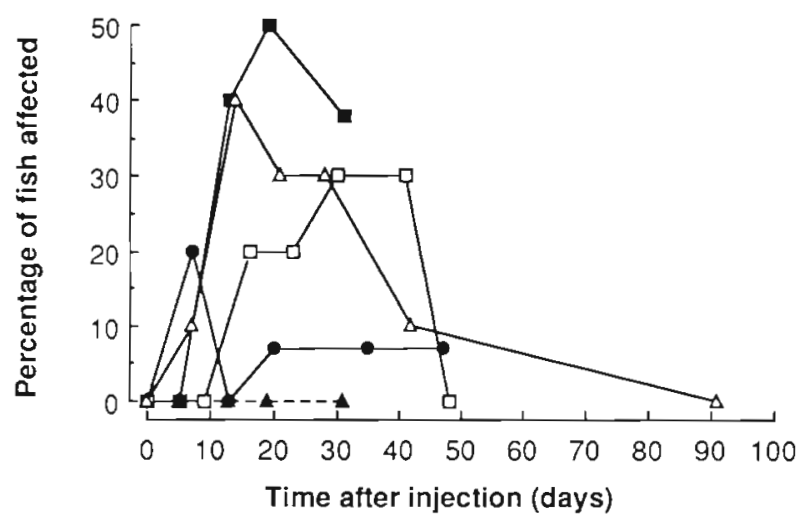

Fig. 4. Salmo salar. Results from 4 experiments showing the development of widespread acinar cell loss in populations of post-smolts in sea water. Each point represents a subsample of 10 fish from initial populations of $70 \mathrm{fish}$. All fish were in jected with kidney homogenates at $30 \mu \mathrm{g}$ protein $\mathrm{g}^{-1}$ body wt. Water temperatures were in the range 13 to $15^{\circ} \mathrm{C}$. Expts 1 and 2 ( and $\mathbf{0}$ ) used the same pool of kidney homogenates, Expts 3 and $4(\square$ and $\triangle)$ used a different kidney homogenate batch. Salmon injected with control material featured in all trials but none developed altered pancreas histology

(A) Control results for Expt 2

nate was increased from 0.03 to $3 \mu \mathrm{g}$ protein $\mathrm{g}^{-1}$ body wt but decreased at higher doses. In a second experiment the prevalence of pancrease disease increased as the kidney homogenate dose increased from 0.3 to $30 \mu \mathrm{g}$ protein $\mathrm{g}^{-1}$ body wt but further increases in the dose of homogenates were associated with a decrease in the incidence of disease.

The results presented in Table 1 show that widespread acinar cell loss can be transmitted by the injection of spleen homogenates and that transmittance can occur between cohabiting fish.

Altered pancreas histology was associated with the absence of food from the gut which was interpreted as evidence that some fish were not feeding. However, not all fish which had pancreas disease were classified as non-feeding and at the peak disease incidence approximately $25 \%$ of fish with pancreas disease had no food in the gut.

\section{DISCUSSION}

In order to enable experimental series to be larger and directly comparable, large pools of homogenised infective and non-infective material were made using the fresh water approach. No fish which received control (non-infective) material had altered pancreas histology when sampled. Additionally, alterations to pancreas histology seen in experimental animals are unlikely to have been due to IPN virus since all batches 
Table 1 Salmo salar. Prevalence of affected fish following transmission by cohabitation in sea water (see 'Methods' for experimental procedures). Results of repeat experiment shown in parentheses

\begin{tabular}{|c|c|c|c|c|}
\hline \multirow[t]{2}{*}{ Experimental group } & \multicolumn{4}{|c|}{ Percentage of fish affected } \\
\hline & Week 1 & Week 2 & Week 3 & Week 4 \\
\hline Control homogenate injected & $0(0)$ & $0(0)$ & $0(0)$ & $0(0)$ \\
\hline Cohabited with control fish & $0(0)$ & $0(0)$ & $0(0)$ & $0(0)$ \\
\hline Infective homogenate injected & $0(0)$ & $30(30)$ & $60(40)$ & $60(20)$ \\
\hline Cohabited with infected fish & $0(0)$ & $0\left(^{\mathrm{a}}\right)$ & $80(40)$ & $50(20)$ \\
\hline a Not sampled & & & & \\
\hline
\end{tabular}

of fish and homogenate pools were diagnosed negative prior to their use (Smail \& Munro 1989).

There are difficulties in using histological appearance to describe the time course of progression of any disease. Intermediate conditions between affected and non-affected are difficult to quantify without resort to sophisticated methods of analysis particularly in an organ of diffuse distribution such as the pancreas. It has previously been demonstrated that serial sections throughout the pancreas of affected fish were of similar appearance (McVicar pers. comm.). Therefore, fish were recorded as affected if, in a single section, all the acinar cells of the exocrine pancreas were massively reduced in area and apparently necrotic and no longer contained zymogen granules, as shown in Fig. $2 b$. Because salmon were destructively sampled for histological analysis, data at any 1 sampling interval represent the progression through the population rather than within an individual. Thus, the total numbers of affected salmon may be underestimated by this method particularly if fish move into and out of the affected condition at different timings as might be the case when the time course of expression of the condition appears more prolonged.

The results presented here demonstrate the variability of response seen in attempted experimental transmissions of pancreas disease. The observation that the response seen following injection is dose dependent is perhaps an expected finding and underlines the importance of standardisation of dose. Standardisation of dose can be achieved by the approach adopted here, namely the generation of large pools of infective material to enable several series of trials to be performed using the same pool. Standardisation between pools is achieved by determining the effect of dose, based on protein concentration, for each pool.

Despite standardisation of the dose of injected material, results in fresh water trials are still subject to variability. Some of this variability may be due to the use of histological appearance to diagnose whether fish are affected or not. Most of the experiments involved the sampling of fish for histological appearance at weekly intervals. Perhaps the rate at which fish develop and recover from acinar cell loss is so rapid that diagnosis using histological appearance contains an element of error particularly as intermediate conditions of acinar cell loss are not included in the score of affected fish. The necessity to destructively sample fish makes it difficult to resolve this sampling error.

Though altered pancreas histology following injection of infective material was observed in sea water trials, results were apparently more variable in degree of incidence of affected salmon and in the time course of expression of the altered pancreas condition. Some sea water populations however, have proved refractory, most commonly those which have only recently been transferred to sea water. Such fish can be presumed to be under more stress and initially may be slow to come onto feed as they adapt to the different physiological demands of their new environment (Usher et al. 1991). These factors, and others, may be important in conditioning the differential response seen in sea water.

On both experimental occasions when it was attempted, the very highest doses (greater than $30 \mu \mathrm{g}$ protein $\mathrm{g}^{-1}$ body $\mathrm{wt}$ ) of material injected to sea water fish resulted in reduced incidences of affected fish. In fresh water trials the smaller size of the fish meant that even at the highest doses $\left(30 \mu \mathrm{g}\right.$ protein $\mathrm{g}^{-1}$ body $\mathrm{wt}$ ) the prepared pool of homogenised material had to be diluted (ca 1:10) prior to injection. The larger size of sea water fish, and the desire to maintain the volume of injection constant, meant that undiluted pool material was used at the highest doses given. This apparently paradoxical result may be explained by the presence of inhibitory factors within the homogenised tissues in addition to any causative agent. Dixon (1987) reported a possibly related phenomenon, that extracts of rainbow trout kidney and spleen inhibited plaque production by IPN virus in cell cultures. Dilutions of tissue homogenates greater than 1:50 were required to overcome the inhibitory effect and Dixon (1987) speculated that the inhibitory factor could have been fish extracts which coated virus preventing absorption to the 
cell surface. Alternatively, extracts may have caused virus aggregations and thus reducing the number of infective particles. Dilution of fish extracts may remove fish material from the virus surface and may facilitate the breaking apart of viral aggregations.

In summary, the results reported provide additional confirmation of the hypothesis of McVicar (1987) that the altered pancreas histology associated with pancreas disease is caused by an infectious agent. In further support of this hypothesis is the observation that altered pancreas histology can develop in fish cohabited with animals injected with infective but not control material. It is possible that a toxin present in the initial homogenate material was responsible for the observed alterations to pancreas histology. However, our ability to passage this materiai through 3 subsequenti girouips of fish with all the attendant dilutions and without diminution of response, implies replication of a causative agent during the passage process. Additionally, the cause of the altered pancreas histology seen in the cohabitation experiment is unsatisfactorily explained by the presence of a toxin. That the incidence of affected fish was unaltered by passage of kidney homogenates through a $0.22 \mu \mathrm{m}$ filter argues in favour of the agent being of a viral nature. McVicar (1990) described virallike inclusion bodies in the pancreas cells of fish affected by pancreas disease. However, these viral-like inclusion bodies have not been confirmed as being of viral origin and their relevance to pancrease disease is uncertain. Therefore, confirmation of an infectious agent causing pancreas disease must await the identification and culture of that agent. We believe, the methods which we describe for the experimental trans- mission of the complete pancreas acinar cell loss will result in a more consistent response to infective material and will better enable the search for that possible agent.

Acknowledgements. We gratefully acknowledge the assistance of the SOAFD Fish Cultivation Unit in the maintenance of the fish used in this study. G. Houghton was funded by the Scottish Salmon Growers Association and the Highlands and Islands Enterprise. In addition the following individual contributions are acknowledged: L. McFarlane for IPN virus tests, C. O. Fraser for technical assistance, R. Johnstone for helpful discussions during the preparation of the manuscript and A. H. McVicar for providing the initial kidney homogenate.

\section{LITERATURE CITED}

Dixon, P. F. (1987). Inhibition of infectious pancreatic necrosis virus infectivity by extracts of rainbow trout, Salmo gairdneri Richardson, tissue. J. Fish Dis. 10: 371-378

McVicar, A. H. (1987). Pancreas disease of farmed Atlantic salmon, Salmo salar, in Scotland: epidemiology and early pathology. Aquaculture 67: 71-78

McVicar, A. H. (1990). Infection as a primary cause of pancreas disease in farmed Atlantic salmon. Bull. Eur. Ass. Fish Pathol. 10: 84-87

Munro, A. L. S., Ellis, A. E., McVicar, A. H., McLay, H. A. (1984). An exocrine pancreas disease of farmed Atlantic salmon in Scotland. Helgoländer Meeresunters. 37: $571-586$

Smail, D. A., Munro, A. L. S. (1989). Infective pancreatic necrosis virus in Atlantic salmon: transmission via the sexual products? In: Ahne, W., Kurstak, E. (eds.) Viruses of lower vertebrates. Springer-Verlag, Berlin, p. 292-301

Usher, M. L., Talbot, C., Eddy, F. B. (1991). Effects of transfer to sea water on growth and feeding in Atlantic salmon smolts (Salmo salar L.). Aquaculture 94: 309-326 